\title{
HOW SUCCESSFUL ARE MEMBER STATES WHEN FOLLOWING EU COHESION POLICY PRIORITIES? FOCUS ON THE VISEGRAD FOUR COUNTRIES
}

\author{
Martin Plešivčák* \\ * Comenius University in Bratislava, Faculty of Natural Sciences, Department of Economic and Social \\ Geography, Demography and Territorial Development, Ilkovičova 6, Mlynská dolina, 84215 Bratislava 4, \\ Slovak Republic, martin.plesivcak@uniba.sk
}

\begin{abstract}
How successful are member states when following EU cohesion policy priorities? Focus on the Visegrad Four countries

The study aims to assess the territorial context of EU cohesion policy implementation at the member state level following the Europe 2020 indicators. Special attention is paid to the Visegrad Four countries. The TOPSIS multi-criterion assessment method was used to monitor the progress of the EU member states in three key priorities (smart, sustainable and inclusive growth), but also globally in the context of cohesion policy as such. We concentrate on the cross-cutting years representing the period of the global economic and financial crisis (2010) as well as the post-crisis situation (2015) - the start and the midway point of achieving the Europe 2020 targets. The analysis has produced results confirming that the member states that joined the EU after 2004 have experienced different progress in the areas under consideration. $\mathrm{Ne}$ vertheless, in assessing achievement in cohesion policy as a whole, they were ranked among the EU's most successful nations, of V4 countries especially Poland and Slovakia. This confirms the meaningfulness of the EU cohesion policy which should help new member state to catch up with the more developed ones.
\end{abstract}

Key words: EU cohesion policy, Europe 2020 Strategy, member states, Visegrad Four, TOPSIS method

\section{INTRODUCTION}

At the turn of the centuries, several experts in the field of political economy highlighted the fact that the emerging neo-liberal transformation of the European Union project would lead to an increase in regional disparities, notably by the accession of the new member states from the former Eastern Bloc, that the differences between member states would deepen at the national and regional levels, and ultimately the EU's distribution to the rich West and poor East would only be highlighted (Budd 1997, Agnew 2001 and Hudson 2003).

The situation regarding the implementation of cohesion policy and the strategic planning objectives for the CCE countries and the Visegrad Four countries, have been dealt with in the past by Budd (1997), Bachtler and Downes (2000), Paraskevopoulos and Leonardi (2004), Bruszt (2008), Cotella et al. (2012), Ehrlich et al. (2012), Ferry and McMaster (2013), Dabrowski (2014), Gál and Lux (2014), Káposzta and Nagy (2015), Mrak et al. (2015) and Faragó and Varró (2016).

The aim of this paper is to assess the geographical context concerning the implementation of the EU cohesion policy objectives in light of the indicators set for the period from 2010 to 2015 , to quantify the progress of the member states, not just for these indicators, but the three key priorities of the Europe 2020 strategy (smart, sustainable and inclusive growth) and cohesion policy as a whole. In the final phase of the analysis special emphasis will be placed on the progress of the 
Visegrad Four countries as well as the individual EU geopolitical regions (old vs. new member countries, countries of the western, northern, southern, central and eastern parts of the EU). Are new member countries (joining the EU after 2004), and the region of Central and Eastern Europe (CCE), including the Visegrad Four countries, really making more progress compared to other parts of Europe in the case of Cohesion Policy indicators and its main priorities according to the intention and focus of the EU's cohesion policy?

In addition, our study compares the performance of countries measured by individual cohesion indicators at the time of the global economic and financial crisis on the one hand (2010) and after the crisis on the other (2015), while also representing the midway point in meeting the Europe 2020 objectives.

\section{THEORETICAL BACKGROUND}

Marlier et al. (2010) introduce the Europe 2020 strategy based on its interconnected pillars, key priorities and headline targets. These are supported by several accompanying documents (flagship initiatives) and guidelines. With this logic in mind, Europe 2020 has been organized around three integrated pillars (European Commission 2010a and 2010b) - macroeconomic surveillance, fiscal surveillance and thematic coordination.

The March 2010 European Council agreed to the European Commission's proposal to launch a new Strategy for Jobs and Growth, Europe 2020, based on an enhanced socio-economic policy coordination. According to the European Commission (2010a), Europe 2020 is expected to mutually reinforcing smart growth (strengthening knowledge and innovation as drivers of future growth), sustainable growth (promoting a more resource efficient, greener and more competitive economy) and inclusive growth (fostering and high-employment economy delivering social and territorial cohesion). This priority is about empowering people through high levels of employment, investing in skills, fighting poverty and modernizing labour markets, training and social protection systems to help people anticipate and manage, change and build a cohesive society.

As McCann (2015) notes, there are several studies that confirm the positive effect on economic growth by measures implemented under EU cohesion policy (e.g. de la Fuente and Vives 1995, Cappelen et al. 2003, In't Veld 2007, Gáková et al. 2009, Ferrara et al. 2010, Becker et al. 2012a, Garcilazo and Rodriguez-Pose 2013 and Pellegrini et al. 2013). The contribution of the cohesion policy in the economic field is confirmed by other authors, but they are more cautious (e.g. MidelfartKnarvik and Overman 2002, Soukiazis and Antunes 2006, Becker et al. 2012b, Filippetti and Peyrache 2015). Finally, the last group of studies question the positive contribution of the EU's cohesion policy (e.g. Fagerberg and Verspagen 1996, Dall'erba and Hewings 2003, Rodriguez-Pose and Fratesi 2004, Dall'erba and LeGallo 2008), some, in relation to economic growth, even speak of its negative impact (e.g. Dall'erba and LeGallo 2007, Dall'erba et al. 2009 and Checherita et al. 2009). McCann (2015) concludes his analysis by stating that more than threequarters of the studies demonstrate the positive effect of EU cohesion policy on the economy of the territorial units. However, these assertions are regionally conditioned, which means that in the context of some subnational units, cohesion policy can have a very positive impact on the economy, but only a minimal or even nega- 
tive impact elsewhere. Several factors such as the national context (Percoco 2013), the institutional background (Garcilazo and Rodriguez-Pose 2013), the implementation process (Becker et al. 2012a) and the impact of territorial units (LeGallo et al. 2011) are mentioned in this context.

Recently, several studies that discuss various aspects and ways of assessing the success of the Europe 2020 strategy have been published. They highlight several key moments as the relationship with the Lisbon Strategy (Walburn 2010), public financial expenditures (Hoedl 2011) market power Europe (Damro 2012), recent EU poverty and social exclusion (Copeland and Daly, 2012). Possible ways of resolving existing methodological problems (such as measuring progress towards the objectives of the Strategy) are proposed, for example, by Pasimeni (2013) and Rappai (2016). The empirical part of our study will focus on the dynamics of cohesion indicators for individual member states, evaluating them in the context of the priorities of the Europe 2020 strategy in the mid-term (2010-2015).

\section{METHODOLOGY}

In the empirical part of the study we utilised eleven Europe 2020 headline indicators at a national level for 2010 - 2015 (Tab. 1), which are divided into three areas to monitor progress in the key priorities of Cohesion Policy (European Commission 2010a).

Tab. 1. The Europe 2020 global priorities and headline indicators

\begin{tabular}{|c|c|c|}
\hline Smart Growth & Sustainable Growth & Inclusive Growth \\
\hline $\begin{array}{l}\text { A Growth index of employment } \\
\text { rate (age group 20-64) } \\
\text { B Growth index of gross do- } \\
\text { mestic expenditure on R\&D } \\
\text { (\% of GDP) }\end{array}$ & $\begin{array}{l}\text { C Growth index of greenhouse } \\
\text { gas emissions } \\
\text { D Growth index of share } \\
\text { of renewable energy in gross } \\
\text { final energy consumption (\%) } \\
\text { E Growth index of primary } \\
\text { energy consumption (million } \\
\text { tonnes of oil equivalent) } \\
\text { F Growth index of final } \\
\text { energy consumption (million } \\
\text { tonnes of oil equivalent) }\end{array}$ & $\begin{array}{l}\text { G Growth index of early } \\
\text { leavers from education and } \\
\text { training (\% of the population } \\
\text { aged } 18-24) \\
\text { H Growth index of tertiary } \\
\text { educational attainment (age } \\
\text { group 30-34) } \\
\text { I Growth index of people at } \\
\text { risk of poverty or social } \\
\text { exclusion (\% of total } \\
\text { population) } \\
\text { J Growth index of people liv- } \\
\text { ing in households with very } \\
\text { low-work intensity (thousand } \\
\text { persons) } \\
\text { K Growth index of severely } \\
\text { materially deprived people } \\
\text { (thousand persons) }\end{array}$ \\
\hline
\end{tabular}

Source: Eurostat (2018).

We did not use Greenhouse gas emissions in ESD Sectors (Sustainable Growth) and People at risk of poverty after social transfers (Inclusive Growth), which we considered to have largely coincided with other indicators entering the analysis. 
We are aware that it was possible to work with data on meeting the agreed target values. However, the growth index shows the progress of individual countries in improving the economic, environmental and social situation as well, also in the context of the Europe 2020 strategy, as we are working with the Europe 2020 headline indicators. In addition, the agreed target values are the result of political agreements, which may be little or much too ambitious for several countries (especially if the target value is the same for all member countries, regardless of their initial socio-economic level). The real progress of individual countries in a given area and for a given period of time can thus be more accurately captured by a simple indicator of the growth index, without linking to the target value (fulfilment of the target in $\%)$.

In defining and assessing the geopolitical and regional units of the EU, we proceeded from the following breakdown (Tab. 2).

Tab. 2.Division of the European Union into geopolitical and regional group of countries

\begin{tabular}{|c|c|c|c|c|c|c|}
\hline $\begin{array}{l}\text { Old member } \\
\text { states } \\
\text { (joined EU } \\
\text { before 2004) }\end{array}$ & $\begin{array}{l}\text { New mem- } \\
\text { ber states } \\
\text { (joined EU } \\
\text { in } 2004, \\
\text { or after) }\end{array}$ & $\begin{array}{l}\text { Northern } \\
\text { part of the } \\
\text { EU }\end{array}$ & $\begin{array}{l}\text { Western part } \\
\text { of the EU }\end{array}$ & $\begin{array}{l}\text { Southern } \\
\text { part of the } \\
\text { EU }\end{array}$ & $\begin{array}{l}\text { Central and } \\
\text { Eastern part } \\
\text { of the EU }\end{array}$ & $\begin{array}{l}\text { Visegrad } \\
\text { Four }\end{array}$ \\
\hline $\begin{array}{c}\text { Austria } \\
\text { Belgium } \\
\text { Denmark } \\
\text { Finland } \\
\text { France } \\
\text { Germany } \\
\text { Greece } \\
\text { Ireland } \\
\text { Italy } \\
\text { Luxembourg } \\
\text { Netherlands } \\
\text { Portugal } \\
\text { Spain } \\
\text { Sweden } \\
\text { United } \\
\text { Kingdom }\end{array}$ & $\begin{array}{c}\text { Bulgaria } \\
\text { Croatia } \\
\text { Cyprus } \\
\text { Czechia } \\
\text { Estonia } \\
\text { Hungary } \\
\text { Latvia } \\
\text { Lithuania } \\
\text { Malta } \\
\text { Poland } \\
\text { Romania } \\
\text { Slovakia } \\
\text { Slovenia }\end{array}$ & $\begin{array}{c}\text { Denmark } \\
\text { Finland } \\
\text { Sweden }\end{array}$ & $\begin{array}{l}\text { Austria } \\
\text { Belgium } \\
\text { France } \\
\text { Germany } \\
\text { Ireland } \\
\text { Luxembourg } \\
\text { Netherlands } \\
\text { United } \\
\text { Kingdom }\end{array}$ & $\begin{array}{c}\text { Cyprus } \\
\text { Greece } \\
\text { Italy } \\
\text { Malta } \\
\text { Portugal } \\
\text { Spain }\end{array}$ & $\begin{array}{c}\text { Bulgaria } \\
\text { Croatia } \\
\text { Czechia } \\
\text { Estonia } \\
\text { Hungary } \\
\text { Latvia } \\
\text { Lithuania } \\
\text { Poland } \\
\text { Romania } \\
\text { Slovakia } \\
\text { Slovenia }\end{array}$ & $\begin{array}{c}\text { Czechia } \\
\text { Hungary } \\
\text { Poland } \\
\text { Slovakia }\end{array}$ \\
\hline
\end{tabular}

Source: Author's own elaboration.

To evaluate the position of the country under study in mutual comparison based on the values of the set of indicators mentioned above, we use the TOPSIS method that finally generates a score for cohesion (European Commission 2010a) priorities as well as an overall cohesion policy.

The highest values of the A, B, D, and $\mathrm{H}$ indicators (the greatest increase, the better), and the lowest values of the C, E, F, G, I, J and $\mathrm{K}$ indicators (the greatest decrease, the better) were accelerators increasing the resulting score. Each indicator was equally weighted in the overall result by $1 / 11$. 
TOPSIS method (Technique for Order Preference by Similarity to Ideal Solution) originally developed by Hwang and Yoon (1981) is known as one of the most classical multi-criteria decision-making method (e.g. see also Opricovic and Tzeng 2004, Shih et al. 2007 and Manokaran et al. 2011).

It constitutes a representative of shortcut methods designed to minimize the distance from the ideal solution. These methods use an ideal variant as the object of aspiration. The selected "best" compromise variant is then the one that is according to the selected metrics the closest to ideal option.

TOPSIS method provides a complete ordering of all variants. To solve the problem, the multi-criteria decision matrix as well as weight vector of individual criteria have to be found out. The main principle of this method is to identify such a variant that is closest to the positive ideal solution, and farthest from the negative ideal solution.

The calculation procedure is as follows:

1) To calculate a normalized multi-criteria decision matrix

$$
R=\left(r_{i j}\right)
$$

using the formula:

$$
r_{i j}=\frac{y_{i j}}{\left(\sum_{i=1}^{p}\left(y_{i j}\right)^{2}\right)^{\frac{1}{2}}},
$$

$i=1,2, \ldots, p, j=1,2, \ldots, k$.

After this transformation, the columns in the matrix are vectors of unit size by Euclidean metrics.

2) To calculate a weighted multi-criteria decision matrix

$$
W=\left(w_{i j}\right)
$$

the way that the $j$-th column is multiplied by the appropriate weight, as follows

$w_{i j}=\left(v_{j} r_{i j}\right)$

3) To determine a positive ideal solution

$$
H_{j}=\left(\max _{i} w_{i j}\right)
$$

$j=1,2, \ldots, k$,

and negative ideal solution

$$
D_{j}=\left(\min _{j} w_{i j}\right) \text {, }
$$

$j=1,2, \ldots, k$.

4) To calculate the distance from a positive ideal solution using the formula as follows:

$$
\begin{aligned}
& d_{i}^{+}=\left(\sum_{j=1}^{k}\left(w_{i j}-H_{j}\right)^{2}\right)^{\frac{1}{2}}, \\
& i=1,2, \ldots, p,
\end{aligned}
$$


and from a negative ideal solution using the formula below:

$$
\begin{aligned}
& d_{i}^{-}=\left(\sum_{j=1}^{k}\left(w_{i j}-D_{j}\right)^{2}\right)^{\frac{1}{2}}, \\
& i=1,2, \ldots, p .
\end{aligned}
$$

For calculation of distance, the Euclidean distance measure was utilised.

5) To calculate a relative distance from a negative ideal solution using the formula below:

$$
\begin{gathered}
c_{i}=\frac{d_{i}^{-}}{d_{i}^{+}+d_{i}^{-}}, \\
i=1,2, \ldots, p .
\end{gathered}
$$

Variants are then arranged in descending order according to the $c_{i}$ values.

The decision for the chosen method is based on the findings of the recent research, e.g. Hajduchová (2016), which confirm that the use of multi-criteria evaluation methods produces identical and, if not, then almost identical results. In this research, the several methods of multi-criteria evaluation were compared each other. The first of them is a method requiring ordinal information on variants according to each criterion (method of ranking). The others belong to the group of methods using cardinal information on variants according to each criterion. The representatives of them are benefit maximization methods (weighted sum method, basic variant method, AHP method and scoring method), as well as method minimizing the distance from the ideal variant. Method of maximum distance from basal variant, known also as TOPSIS method, is one of them, too. At the end of her work, the author states that the resulting evaluation (order) of the entities under study (in her case different variants of construction, in our case the EU Member States) is the same when using any of the mentioned methods. In our research we decided to use the latter method, the TOPSIS method. Originally, this method is used to sort the variants of the solution in decision-making. Analogously, however, it can also be used e.g. in the case of assessing the progress of countries in the context of the EU cohesion policy, with a view to meeting the Europe 2020 objectives. Under this method, countries are peer-reviewed against the outcome of the most successful and least successful country in a given indicator (priority, or overall), which can be welcomed, as the cohesion policy focuses primarily on the issue of differences between the most successful and least successful countries, or their regions.

Calculations, chart and table attachments were developed in Microsoft Excel 2010, maps in MapInfo Professional 9.5.

\section{RESULTS}

\section{Cohesion Indicators \\ Coefficient of variation}

In the next phase of the analysis, we took a closer look at the variation in the progress of the values of each indicator in achieving the three main priorities of the 
Europe 2020 strategy (smart, sustainable and inclusive growth - Fig. 1). EU countries are most similar to each other in developing primary energy consumption (Coefficient of variation / $\mathrm{CV}=5.02)$, greenhouse gas emissions $(\mathrm{CV}=6.09)$, employment rate $(\mathrm{CV}=6.34)$ and final energy consumption $(\mathrm{CV}=6.85)$. On the contrary, the biggest differences in the development of values were monitored among member states in relation to severely materially deprived people $(\mathrm{CV}=50.14)$ and renewable energy in final energy consumption $(\mathrm{CV}=48.26)$.

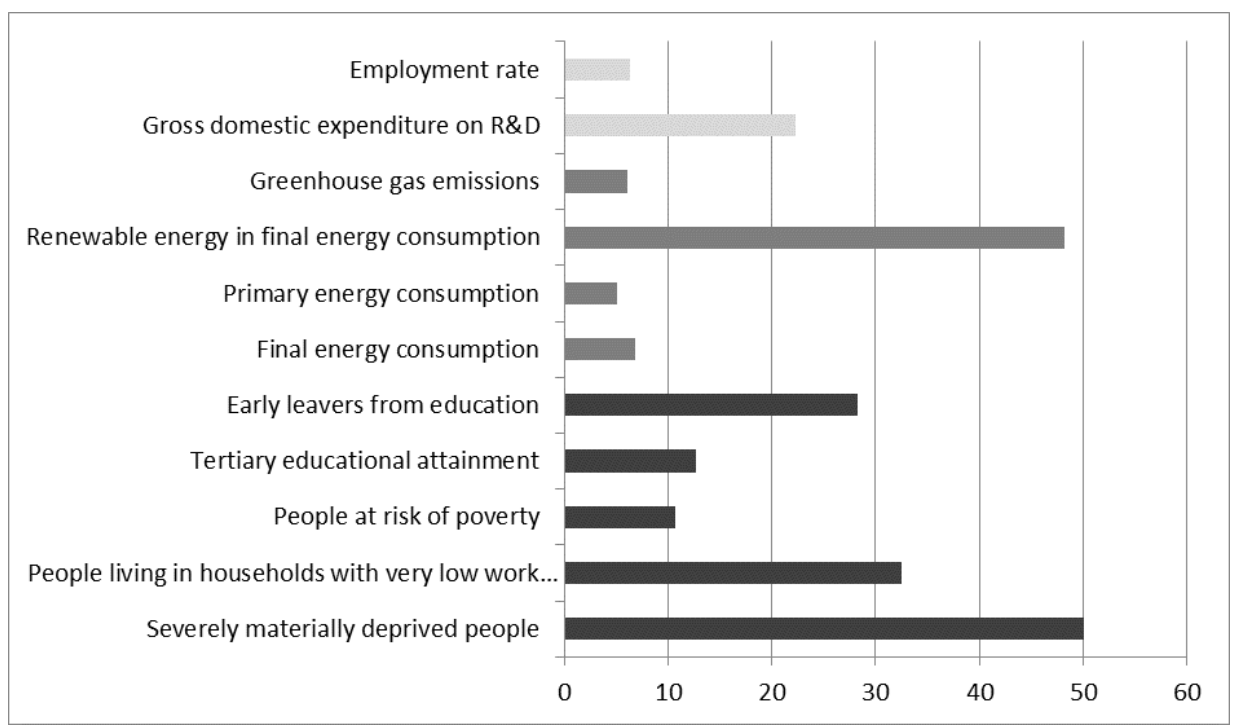

Fig. 1. Coefficient of variation related to indicators under study (based on Growth index data)

Source: Eurostat (2018), Author's own elaboration.

At the level of the priorities of the strategy (Fig. 2), member states are progressing at the most similar rate in the case of the Smart Growth (18.38), while the priority of Inclusive Growth shows a value of 32.39 and the greatest difference is demonstrated for the priority of Sustainable Growth (40.59). In this context, however, it is important to state that if we did not take into consideration the extreme value of renewable energy and final energy consumption in the field of environment and energy, in particular due to the aforementioned dynamic growth in the share of renewable energy in the final energy consumption of Malta, Sustainable Growth would represent the area in which states have progressed most uniformly. This is confirmed by the above-mentioned fact that three of the four indicators with the lowest variability of values are from the area of the environment and energy (Sustainable Growth). The area of knowledge-based economy (Smart Growth) is the second most successful area. The biggest problem in terms of joint development in achieving the Europe 2020 targets was registered for the social sphere (Inclusive Growth). 


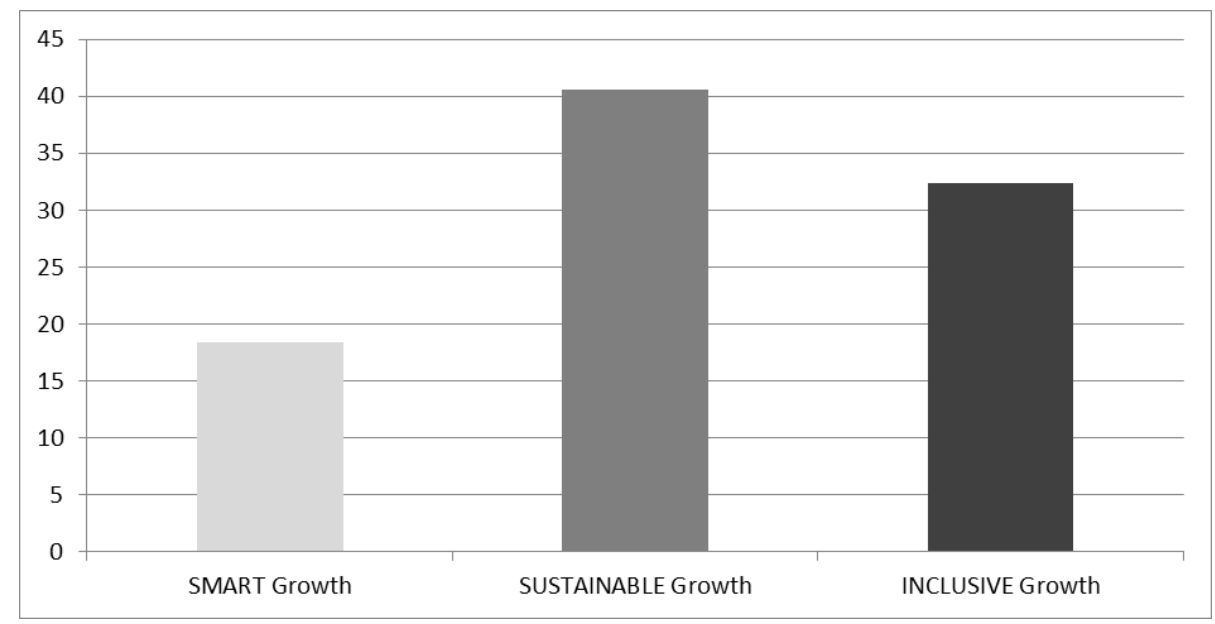

Fig. 2. Coefficient of variation related to three global Europe 2020 priorities (based on Growth index data)

Source: Eurostat (2018), Author's own elaboration.

\section{Europe 2020 Priorities}

\section{Growth Index}

In this passage of the study, we will look more closely at the success of the EU countries in the progress of the values of the indicators for the individual priorities (smart, sustainable and inclusive growth) and altogether (i.e. overall in relation to the Europe 2020 strategy as such). We used the TOPSIS multi-criteria evaluation method for assessing individual areas of several indicators and their values. In the case of the Smart Growth priority (Fig. 3), Slovakia (TOPSIS Score $=0.906$ ) and Bulgaria (0.807) recorded the greatest progress between 2010 and 2015, followed by Ireland (0.656), Greece (0.645) and Czechia (0.610). On the contrary, the worst results in this area were recorded in Finland (0.123), Portugal (0.124), Luxembourg $(0.152)$ and Spain (0.160). In advanced economies such as those of Finland and Luxembourg, it can be expected that high employment and science and research expenditures were achieved in the previous period, which likely resulted in saturation ("ceiling") in the next period. Except for Slovakia and Czechia, the other V4 countries also performed relatively well, as they exceeded the EU average (0.278) in the area of Smart Growth (Poland - 0.553 and Hungary - 0.434). Looking at the spatial distribution of TOPSIS scores for Smart Growth priority, we can generally conclude that the "new" member countries from Central and Eastern Europe (joining EU after 2004) have made more progress in this question over the 2010 to 2015 period compared to the "old" member states, which is in line with the meaning and objectives of EU cohesion policy. 


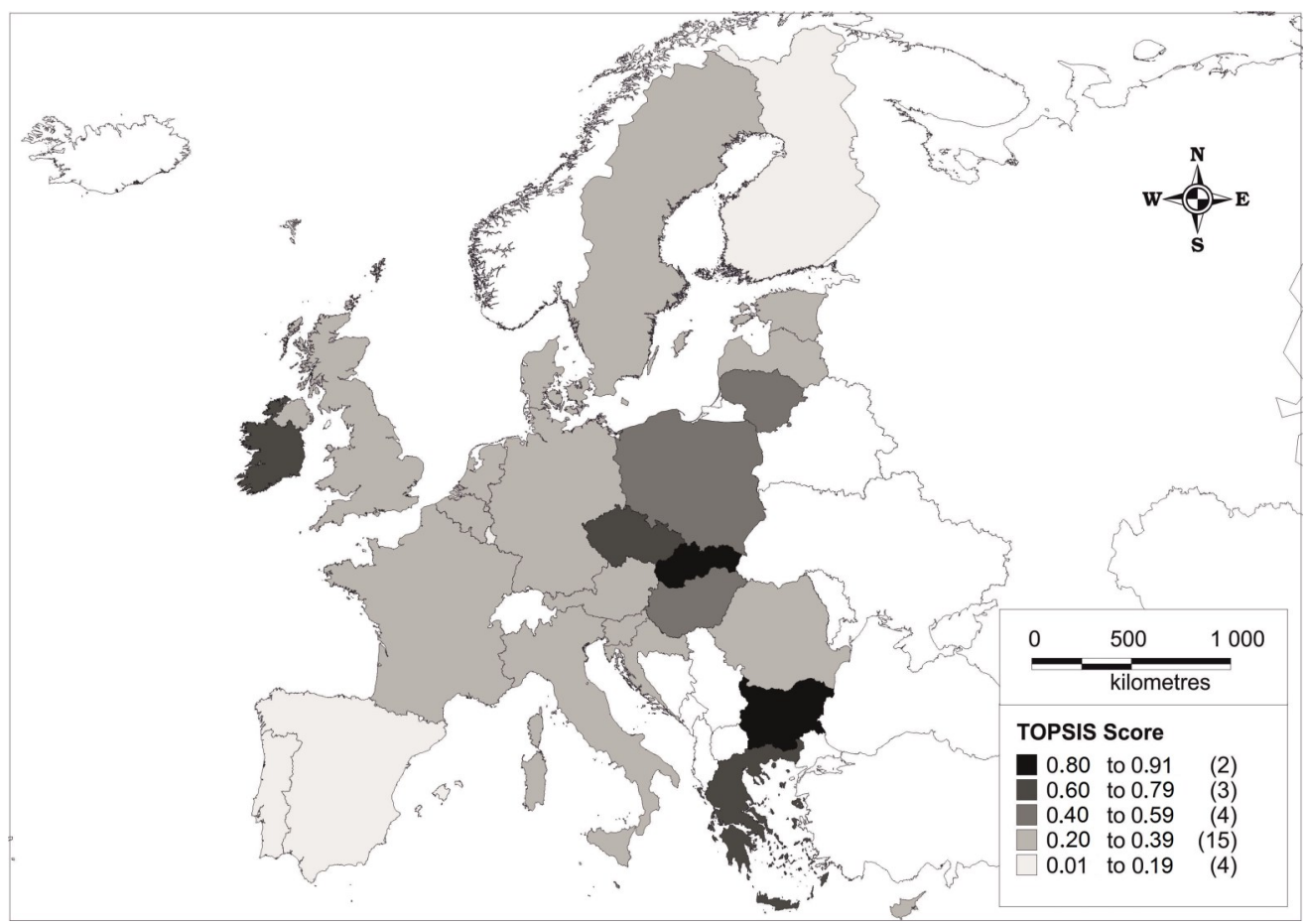

Fig. 3. TOPSIS Score of the EU members states related to Smart Growth priority Source: Eurostat (2018), Author's own elaboration.

In assessing the environment and energy (Fig. 4), the most significant improvement over the first half of the current decade was achieved by Malta $(0.852)$, while the United Kingdom in second place lags behind (0.322). As noted above, Malta contributed to this result in particular by a significant upward shift in relation to the very dynamic growth of its share of renewable energy in gross final energy consumption. However, in the case of other environmental indicators, the growth index of greenhouse gas emissions and growth index of final energy consumption, Malta is ranked as the least successful Member State. In these cases, the variability of values between countries was not too high). The top 5 was also occupied by Luxembourg, Greece and Cyprus (values just above 0.200). On the other hand, Bulgaria (0.088), Estonia (0.097), Lithuania (0.111), Romania (0.112) and Austria (0.113) were the worst cases in the cross-country comparison. Hungary was just ahead of this group (0.119) and Poland (0.130) was under the EU average (0.143). Czechia $(0.155)$ and Slovakia $(0.172)$ achieved a better average when assessing progress in the environmental sphere. From the spatial point of view, it is not possible to identify more pronounced trends that would distinguish the old member states from the new member states, and individual geographical macro-regions of Europe. 


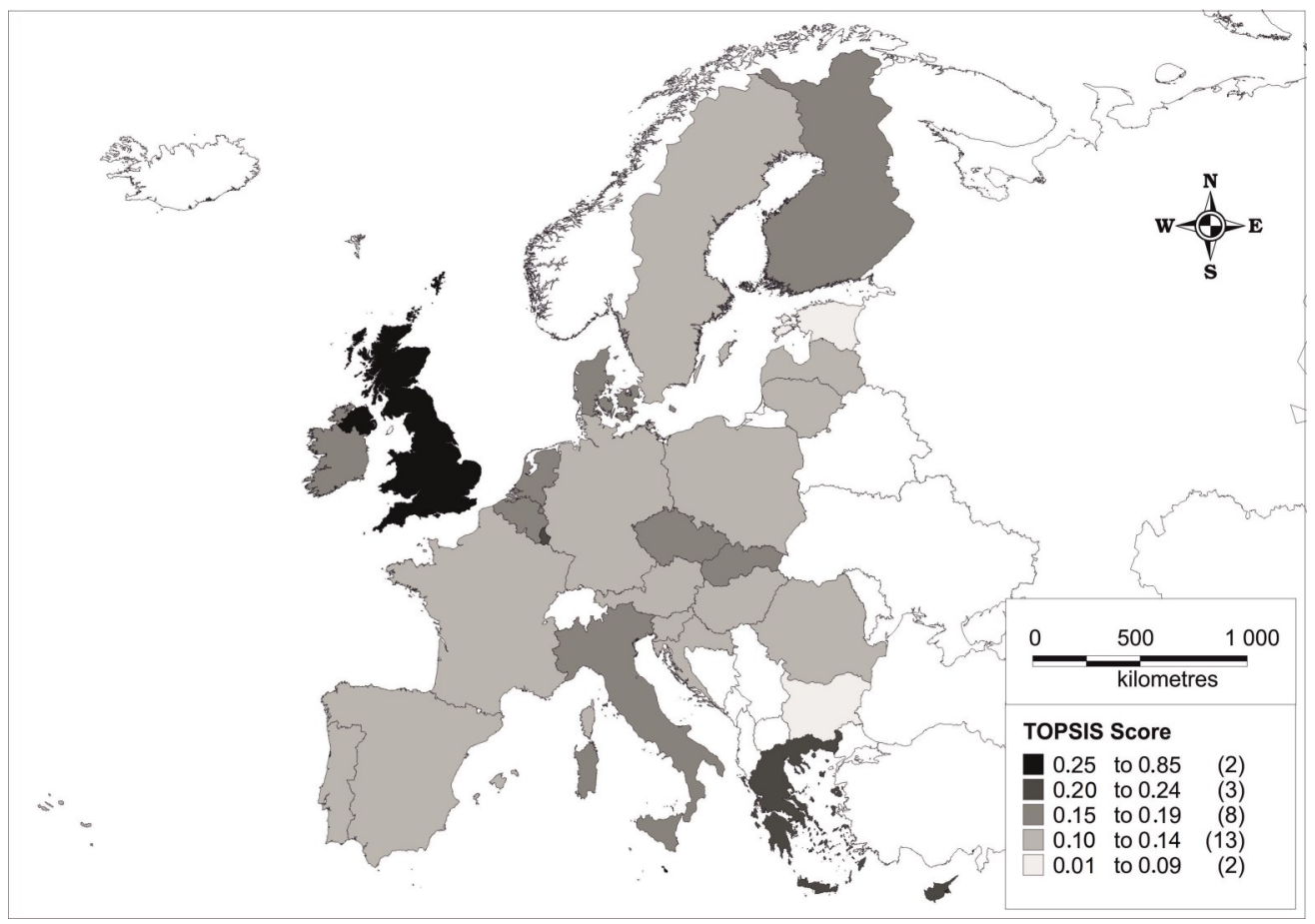

Fig. 4. TOPSIS Score of the EU members states related to Sustainable Growth priority Source: Eurostat (2018), Author's own elaboration.

When assessing social progress (Inclusive Growth priority), there are also several interesting facts (Fig. 5). The most significant step forward in this case has been taken by Latvia $(0.850)$ and Lithuania $(0.838)$. Behind them were Croatia (0.796), France (0.783) and Poland (0.775). Luxembourg (0.298), Greece (0.464) and Cyprus (0.531) were at the opposite end of the list, with the least significant progress in the social sphere between 2010 and 2015. Poland was the most successful of the V4 countries in this comparison, with Hungary achieving the same value as the EU average (0.740). Czechia (0.681) and Slovakia (0.666) joined the ten countries with the least progress in achieving Inclusive Growth priority.

At the final stage of the research, we were interested in how the member states were doing in following the Europe 2020 priorities globally (Fig. 6), taking into account their outcomes for all areas of concern (priorities). From this point of view, Malta was the most successful country $(0.730)$, followed by Latvia $(0.543)$ and Lithuania (0.539). The United Kingdom (0.531) and Poland (0.528) were also part of the Top 5. Slovakia can also be seen as successful, as it ranked sixth overall (0.518). The top ten is rounded out by Ireland, Estonia, France and Croatia. Czechia and Hungary, achieved a slightly higher value compared to the EU average, and ranked 12 th and 15 th respectively. The least successful country was Luxembourg (0.268), followed by Greece (0.393), Cyprus (0.421), Spain (0.427) and 
Italy (0.434). From a spatial point of view, we can conclude several interesting findings. Within Western and Eastern Europe, two contiguous clusters of countries with above average progress in achieving the Europe 2020 priorities were formed. The first band of countries ranges from the Baltic countries through Poland and Slovakia to Croatia (excluding the "average" Hungary). The second significant concentration of contiguous countries with above-average progress in smart, sustainable and inclusive growth is located in Western Europe and consists of Ireland, Great Britain and France. These two spatial units are formed only of countries exclusively from the top ten of the resulting evaluation. They are complemented by Malta, which dominates the rating.

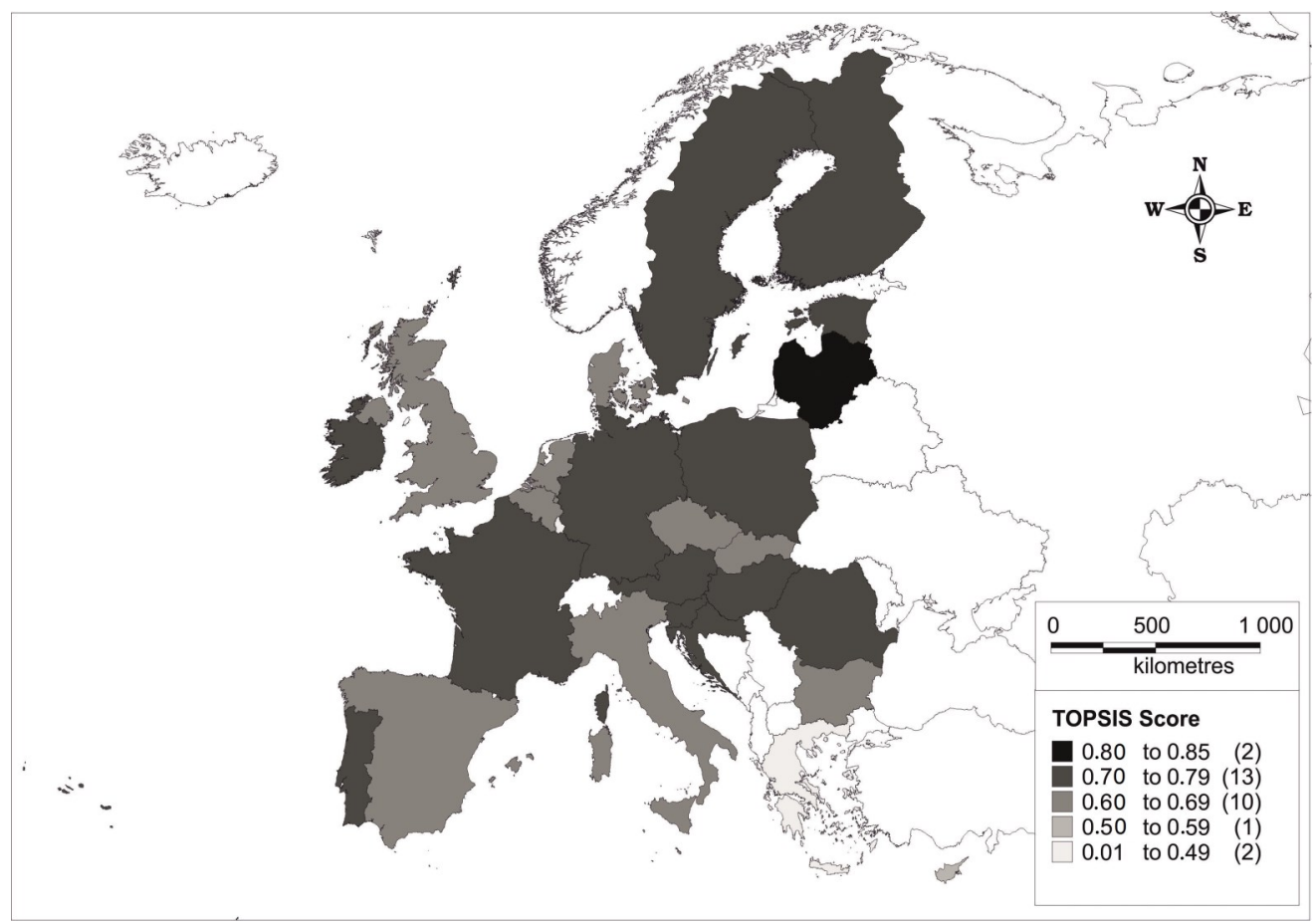

Fig. 5. TOPSIS Score of the EU members states related to Inclusive Growth priority

Source: Eurostat (2018), Author's own elaboration.

Finally, the results of the research were analysed within the historical and geographical context of the EU. We have evaluated the success of old and new member countries (member countries joining EU before and after 2004), and compared the southern, western, northern, central and eastern parts of the EU as well as the Visegrad Four (Tab. 3). It was determined that the new member states made more progress in the areas surveyed between 2010 and 2015 compared to the old ones, which, given the meaningfulness and justification of the existence of EU regional and cohesion policy itself, can be very positive. The average overall ranking of the 
13 member countries joining the EU after 2004 was 10.7 with an average TOPSIS score of 0.520 . The group of old member countries achieved a value of 0.463 , with a significantly worse average ranking (17.8). If we compare the above-mentioned geo-historical parts of Europe, we find that the Visegrad Four countries as well as of Central and Eastern Europe managed to progress the most with an average ranking of 9.5 (value of 0.511 ) and $10.2(0.509)$ respectively. The Western European countries showed an average ranking of 14.6 (0.471), Northern Europe had an average ranking of 18.7 (0.479) and Southern Europe recorded an average ranking of $20.2(0.481)$. It may be appreciated that cohesion policy at the country level really helps the "less developed" countries (younger EU members); nevertheless the pessimistic stagnation of the Southern Europe countries can be perceived as well, as they are located behind the much more advanced western and northern European countries when assessing the progress between the crisis and post-crisis periods as well as "midway" towards the target values concerning priority areas of the Europe 2020 strategy.

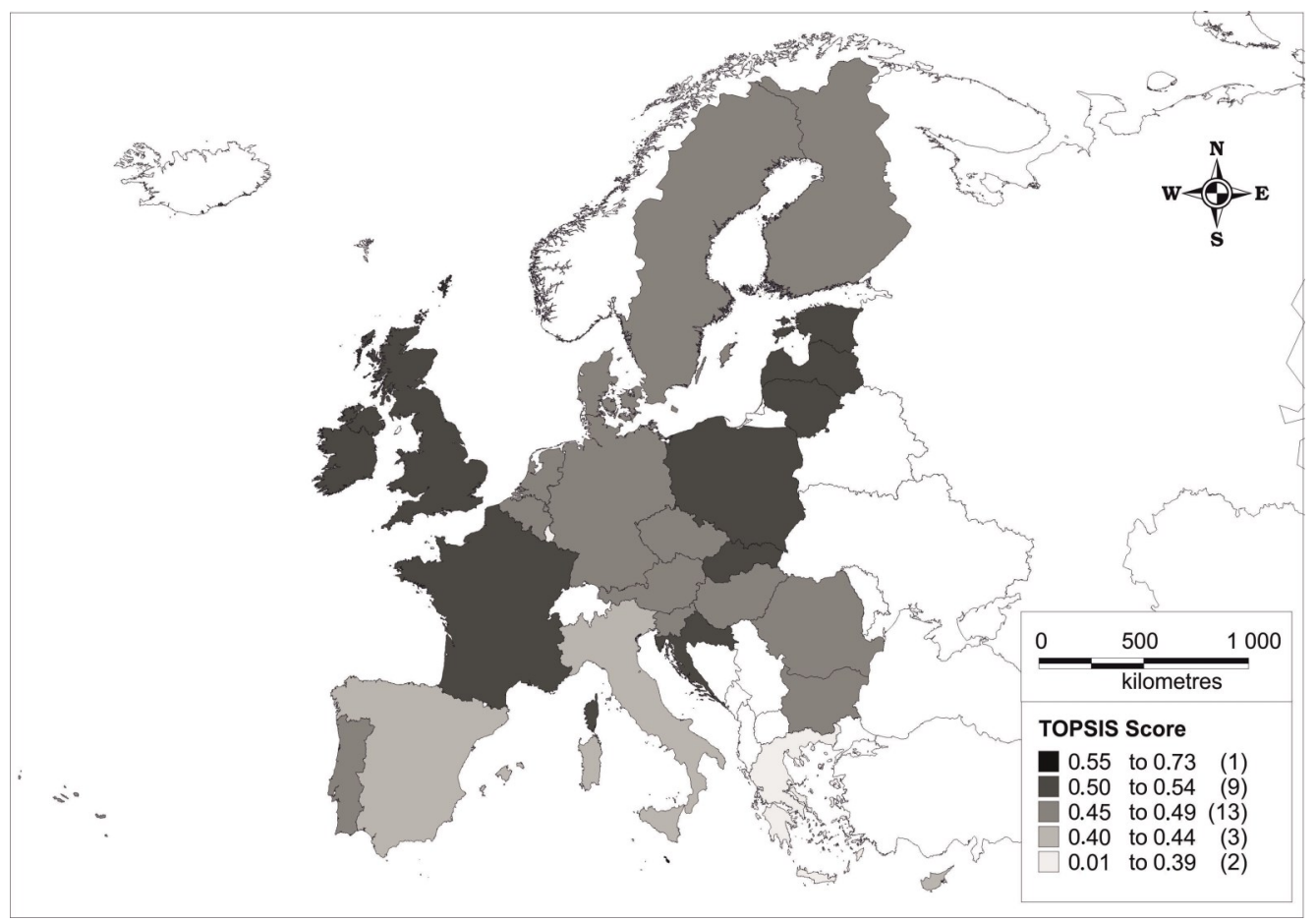

Fig. 6. TOPSIS Score of the EU members states related to Overall Growth Source: Eurostat (2018), Author's own elaboration. 
Tab. 3. TOPSIS Score of the EU members states related to Overall Growth

\begin{tabular}{rcccccccc}
\hline Order & Country & $\begin{array}{c}\text { TOPSIS } \\
\text { Score }\end{array}$ & Order & Country & $\begin{array}{c}\text { TOPSIS } \\
\text { Score }\end{array}$ & $\begin{array}{c}\text { Average } \\
\text { Order }\end{array}$ & Macro-region & $\begin{array}{c}\text { Average } \\
\text { TOPSIS } \\
\text { Score }\end{array}$ \\
\hline 1 & Malta & 0.730 & 15 & Hungary & 0.497 & 9.5 & Visegrad Four & 0.511 \\
2 & Latvia & 0.543 & 16 & Romania & 0.494 & 10.2 & Central and Eastern EU & 0.509 \\
3 & Lithuania & 0.539 & 17 & Austria & 0.492 & 10.7 & $\begin{array}{c}\text { New member states } \\
\text { (after 2004) }\end{array}$ & 0.520 \\
4 & United Kingdom & 0.531 & 18 & Portugal & 0.481 & 14.6 & Western EU & 0.471 \\
5 & Poland & 0.528 & 19 & Finland & 0.480 & 17.8 & Old member states (before & 0.463 \\
6 & Slovakia & 0.518 & 20 & Belgium & 0.480 & 18.7 & Northern EU & 0.479 \\
7 & Ireland & 0.515 & 21 & Netherlands & 0.474 & 20.2 & Southern EU & 0.481 \\
8 & Estonia & 0.510 & 22 & Slovenia & 0.469 & - & European Union & 0.490 \\
9 & France & 0.508 & 23 & Denmark & 0.461 & & & \\
10 & Croatia & 0.506 & 24 & Italy & 0.434 & & & \\
11 & Germany & 0.499 & 25 & Spain & 0.427 & & & \\
12 & Czechia & 0.499 & 26 & Cyprus & 0.421 & & &
\end{tabular}

Source: Eurostat (2018), Author's own elaboration.

\section{DISCUSSION}

More than a decade after the largest expansion of the European Union predominantly to Central and Eastern Europe, including the Visegrad Four countries, it turned out that there was economic convergence at a national level, yet the differences between the regions have gradually widened over time (Smith and Timár 2010 and Monastiriotis 2011). In the context of the Europe 2020 strategy implemented in 2010, geared to smart, sustainable and inclusive growth, EU cohesion policy continues to emphasize the need to foster competitiveness, focus on the concept of urban areas, but also its complementarity to the objectives of other "flagship" EU policies. According to Mendez (2013), excessive concentration on the Europe 2020 strategy objectives, in the context of the public budget crisis at the turn of decades, has led to the recognition that a cohesion policy had been oriented at the national rather than the regional level. In addition, the national dimension of this strategy has been reinforced by the Commission's country-specific recommendations as well as by the signing of partnership agreements with national authorities. Excessive focus on the objectives of the Europe 2020 strategy inevitably leads to a situation where less attention is paid to sub-national territorial issues and the problems of specific regions, cities and municipalities (Mendez et al. 2013).

In coordination with domestic policy makers, the contribution of regional players to territorial development issues is very limited, and regional strategies are more pragmatically oriented on the creation of opportunities at the highest, panEuropean level (Bachtler and McMaster 2008, Dąbrowski 2014 and Varró and Faragó 2015). From among the Visegrad Four countries, only in the case of Poland has cohesion policy been decentralized to a sub-national, regional level, but this is also due to the population and territorial size of the country itself and its regional 
entities. In the other countries of the region, the principle of the centralized management of EU funds is dominated by the responsible national authority.

Given the continued prevalence of macroeconomic conditionality and the inadequate adaptation of strategic planning to the conditions of CEE countries with the inheritance of post-socialist transformation, the effectiveness of cohesion policy to achieve its objectives remains rather controversial. Several studies questioned the assumption that the fruit of economic growth in the richer regions subsequently generates a similar trend in economically less developed countries (Dunford and Perrons 1994, Budd 2007 and Monastiriotis 2011). These findings were also supported by the political statement by the European Commission President JeanClaude Juncker, who, in his inaugural speech, acknowledged the need for a twospeed Europe concept (Juncker 2014). In spite of the announced economic convergence of the EU member states at the national, not sub-national, regional levels, some authors note widening social disparities across EU member states (e.g. Tilfor and Whyte 2010 and Petmesidou 2017). Our research has shown that in the environmental field, member states are progressing similarly (low variance of progress values - except for the extreme case of Malta and the indicator of renewable energy in gross final energy consumption).

\section{CONCLUSION}

The study focused on assessing the success of member states in achieving progress in the main indicators of the EU cohesion policy, with a particular focus on the Visegrad Four countries. Slovakia, Czechia, Poland and Hungary were highly above average in following the Smart Growth priority, with average Sustainable Growth and Inclusive Growth results. In the overall assessment (for all three global priorities), they rank among above-average (Poland - 5th, Slovakia - 6th, Czechia -12 th, and Hungary -15 th).

However, there are some limitations related to the results and their informative value. A comparison of the progress of values, not their current level was carried out (cohesion should be connected to convergence when considering the EU regional policy). It does not reflect how far recent values are from the target values (not evaluated due to drawbacks, such as data inconsistency, target values determined by countries themselves, etc.). Therefore, further research is needed, requiring better data, even at the NUTS2, and NUTS 3 levels (lack of consistent data).

The assessment was to a certain extent influenced by the population size and level of economic development of the individual countries, as the two smallest EU countries, Malta and Luxembourg, occupied high positions. In smaller and less developed countries, one larger project, or a series of projects (measures taken), mainly related to one specific issue, can cause a relatively large shift forward for the country as a whole over a relatively short period. In Luxembourg (and other countries with a developed economy and a very high standard of living), it is also necessary to consider the possible state of saturation (they are "too developed" which limits the scope for their further, more dynamic shift). Another problematic issue relates to whether the progress that is being monitored is partly due to national policy measures rather than European ones.

There is a need to monitor both national and sub-national differences, since positive values for the country as a whole do not necessarily mean that the state of society is improving for the benefit of the majority, living in the economically, envi- 
ronmentally and socially differently developed EU regions and member states. However, the existence of a comprehensive database of cohesion policy indicators at the NUTS2 level and below is an indispensable condition for the monitoring of these sub-national trends.

This paper was prepared with the support provided by research grant of the Slovak Research and Development Agency APVV-17-0079 "Population Analysis and Forecast of the Slovak Republic in Time-horizon 2080: Identification and Modelling the Impacts on Society in Different Spatial Scales ".

\section{REFERENCES}

AGNEW, J. (2001). How many Europes? The European Union, eastward enlargement and uneven development. European Urban and Regional Studies, 8, 29-38. DOI: $10.1177 / 096977640100800103$.

BACHTLER, J., DOWNES, R. (2000). The spatial coverage of regional policy in Central and Eastern Europe. European Urban and Regional Studies, 7, 159-174. DOI: $10.1177 / 096977640000700205$.

BACHTLER, J., MCMASTER, I. (2008). EU Cohesion policy and the role of the regions: investigating the influence of Structural Funds in the new member states. Environment and Planning C Government and Policy, 26, 398-427. DOI: 10.1068/c0662.

BECKER, S. O., EGGER, P. H., von EHRLICH, M. (2012a). Too much of a good thing? On the growth effects of the EU's regional policy. European Economic Review, 56, 648 -668. DOI: 10.1016/j.euroecorev.2012.03.001.

BECKER, S. O., EGGER, P. H., von EHRLICH, M. (2012b). Absorptive capacity and the growth and investment effects of regional transfers: regression discontinuity design and with heterogeneous treatment effects. CAGE Working Paper, No. 89. Coventry (University of Warwick), p. 58.

BRUSZT, L. (2008). Multi-level governance - the Eastern versions: Emerging patterns of regional development governance in the new member states. Regional and Federal Studies, 18, 607-627. DOI: 10.1080/13597560802351622.

BUDD, L. (1997). Regional integration and convergence and the problems of fiscal and monetary systems: Some lessons for Eastern Europe. Regional Studies, 31, 559-570. DOI: $10.1080 / 00343409750131695$.

BUDD, L. (2007). A cohesion pact for the regions. Policy Studies, 28, 347-363. DOI: 10. 1080/01442870701640724.

CAPPELEN, A., CASTEllaCCI, F., FAGERBERG, J., VERSPAGEN, B. (2003). The impact of EU regional support on growth and convergence in the European Union. Journal of Common Market Studies, 41, 621-644. DOI: 10.1111/1468-5965.00438.

CHECHERITA, C., NICKEL, C., ROTHER, P. (2009). The role of fiscal transfers for regional economic convergence in Europe. ECB Working Paper, No. 1029. Frankfurt am Main (European Central Bank), p. 41.

COPELAND, P., DALY, M. (2012). Varieties of poverty reduction: Inserting the poverty and social exclusion target into Europe 2020. Journal of European Social Policy, 22, 273-287. DOI: 10.1177/0958928712440203.

COTELLA, G., ADAMS, N., NUNES, R. J. (2012). Engaging in European spatial planning: A Central and Eastern European perspective on the territorial cohesion debate. European Planning Studies, 20, 1197-1220. DOI: 10.1080/09654313.2012.673567.

DĄBROWSKI, M. (2014). Towards place-based regional and local development strategies in Central and Eastern Europe? EU cohesion policy and strategic planning capacity at the sub-national level. Local Economy, 29, 378-393. DOI: 10.1177/0269094214535715.

DALLERBA, S., HEWINGS, G. J. D. (2003). European regional development policies: The trade-off between efficiency-equity revisited. REAL Working Paper, No.03-T-2. Regional Economics Applications Laboratory. Champaign (University of Illinois at Urban-Champaign), p. 25. 
DALLERBA, S., LEGALLO, J. (2007). The impact of EU regional support on growth and employment. Czech Journal of Economics and Finance, 57, 325-340.

DALLERBA, S., LEGALLO, J. (2008). Regional convergence and the impact of European structural funds over 1989 - 1999: A spatial econometric analysis. Papers in Regional Science, 87, 219-244. DOI: 10.1111/j.1435-5957.2008.00184.x.

DALLERBA, S., GUILLAIN, R., LE GALLO, J. (2009). Impact of structural funds on regional growth: How to reconsider a 9 year-old black box. Région et Développement, $30,77-99$.

DAMRO, C. (2012). Market power Europe. Journal of European Public Policy, 19, 682699. DOI: $10.1080 / 13501763.2011 .646779$.

DE LA FUENTE, A., VIVES, X. (1995). Infrastructure and education as instruments of regional policy: Evidence from Spain. Economic Policy, 10, 13-51. DOI: $10.2307 / 1344537$.

DUNFORD, M., PERRONS, D. (1994). Regional inequality, regimes of accumulation and economic development in contemporary Europe. Transactions of the Institute of British Geog-raphers, 19, 163-182. DOI: 10.2307/622752.

EHRLICH, K., KRISZAN, A., LANG, T. (2012). Urban development in Central and Eastern Europe - between peripheralization and centralization? The Planning Review, 48, 77-92. DOI: 10.1080/02513625.2012.721611.

EUROPEAN COMMISSION (2010a). Europe 2020: A European strategy for smart, sustainable and inclusive growth. Brussels (European Commission), p. 34.

EUROPEAN COMMISSION (2010b). Governance, tools and policy cycle of Europe 2020. Brussels (European Commission), p. 8.

EUROSTAT (2018). Europe 2020 Headline Indicators. Luxembourg (Statistical Office of the European Union).

FAGERBERG, J., VERSPAGEN, B. (1996). Heading for divergence? Regional growth in Európe reconsidered. Journal of Common Market Studies, 34, 431-443. DOI: 10.1111/ j.1468-5965.1996.tb00580.x.

FARAGÓ, L., VARRÓ, K. (2016). Shifts in EU cohesion policy and processes of peripheralization - a view from Central Eastern Europe. European Spatial Research and Policy, 23, 5-19. DOI: 10.1515/esrp-2016-0001.

FERRARA, A., IVANOVA, O., KANCS, D. (2010). Modelling the policy instruments of the EU cohesion policy. In Working Paper, No.02/2010. Brussels (Directorate-General for Regional Policy), p. 23.

FERRY, M., McMASTER, I. (2013). Cohesion policy and the evolution of regional policy in Central and Eastern Europe. Europe-Asia Studies, 65, 1502-1528. DOI: $10.1080 / 09668136.2013 .832969$.

FILIPPETTI, A., PEYRACHE, A. (2015). Labour productivity and technology gap in European regions: A conditional frontier approach. Regional Studies, 49, 532-554. DOI: 10.1080/00343404.2013.799768.

GARCILAZO, E., RODRIGUEZ-POSE, A. (2013). Quality of government and the returns of investment: Examining the impact of cohesion expenditure in the European regions. In OECD Regional Development Working Papers, No.2013/12. Paris (Organisation for Economic Co-operation and Development), p. 21.

GÁKOVÁ, Z., GRIGONYTÉ, D., MONTFORT, P. (2009). A cross-country impact assessment of EU cohesion policy. In Working Paper, No. 01/2009. Brussels (DirectorateGeneral for Regional Policy), p. 13.

GÁL, Z., LUX, G. (2014). ET2050 Territorial scenarios and visions for Europe. Final report. Project 2013/1/19. Luxembourg (ESPON), p. 21.

HAJDUCHOVÁ, S. (2016). Optimálny výber návrhu objektov zariadenia staveniska. Mladá veda / Young Science, 4, 104-113.

HOEDL, E. (2011). Europe 2020 strategy and European recovery. Problems of Sustainable Development, 6, 11-16. 
HUDSON, R. (2003). European integration and new forms of uneven development but not the end of territorially distinctive capitalisms in Europe. European Urban and Regional Studies, 10, 49-67. DOI: 10.1177/0969776403010001539.

HWANG, C. L., YOON, K. (1981). Multiple attribute decision making: Methods and applications. New York (Springer-Verlag).

IN'T VELD, J. (2007). The potential impact of the fiscal transfers under the EU cohesion policy Programme. In European Economy Economic Papers, No. 283. Brussels (European Commission Directorate-General for Eco-nomic and Financial Affairs), p. 29.

JUNCKER, J-C. (2014). A new start for Europe: My agenda for jobs, growth, fairness and democratic change. Political guidelines for the next European Commission. In Opening Statement in the European Parliament Plenary Session. Strasbourg (European Parliament), p. 36.

KÁPOSZTA, J., NAGY, H. (2015). Status report about the progress of the Visegrad countries in relation to Europe 2020 targets. European Spatial Research and Policy, 22, 81-99. DOI: 10.1515/esrp-2015-0018.

LEGALLO, J., DALLERBA, S., GUILLAIN, R. (2011). The local versus global dilemma of the effects of structural funds. Growth and Change, 42, 466-490. DOI: 10.1111/ j.1468-2257.2011.00564.x.

MANOKARAN, E., SUBHASHINI, S., SENTHILVEL, S., MURUGANANDHAM, R., RAVICHANDRAN, K. (2011). Application of multi criteria decision making tools and validation with optimization technique. Case study using TOPSIS, ANN \& SAW. International Journal of Management \& Business Studies, 1, 112-115.

MARLIER, N., NATALI, D. VAN DAM, R. (2010). Europe 2020 towards a more social $E U$. Bern (Peter Lang). DOI: 10.3726/978-3-0352-6027-4.

McCANN, P. (2015). The regional and urban policy of the European Union. Cohesion, results-orientation and smart specialisation. Cheltenham (Edward Elgar).

MENDEZ, C. (2013). The post-2013 reform of EU cohesion policy and the place-based narrative. Journal of European Public Policy, 20, 639-659. DOI: 10.1080/13501763.2012.736733.

MENDEZ, C., BACHTLER, J., GRANQVIST, K. (2013). European commission perspectives on the $2014-2020$ partnership agreements and programmes: A comparative review of the commission's position papers. European Policy Research Paper, No. 84 . Glasgow (European Policies Research Centre, University of Strathclyde), p. 88.

MIDELFART-KNARVIK, K. H., OVERMAN, H. G. (2002). Delocation and European integration - is structural spending justified? Economic Policy, 17, 323-359. DOI: $10.1111 / 1468-0327.00091$.

MONASTIRIOTIS, V. (2011). Regional growth dynamics in Central and Eastern Europe. In LSE 'Europe in Question' Discussion Paper Series. London (The London School of Economics and Political Science), p. 28.

MRAK, M., RICHTER, S., SZEMLER, T. (2015). Cohesion policy as a function of the EU budget: A perspective from CEE member states. Research Report, No. 400. Vienna (The Vienna Institute for International Economic Studies), p. 115.

OPRICOVIC, S., TZENG, G. H. (2004). Compromise solution by MCDM methods: a comparative analysis of VIKOR and TOPSIS. European Journal of Operational Research, 156, 445-455. DOI: 10.1016/S0377-2217(03)00020-1.

PARASKEVOPOULOS, C. J., LEONARDI, R. (2004). Introduction: adaptational pressures and social learning in European regional policy - cohesion (Greece, Ireland and Portugal) vs. CEE (Hungary, Poland) countries. Regional and Federal Studies, 14, 315-354. DOI: $10.1080 / 1359756042000261342$.

PASIMENI, P. (2013). The Europe 2020 index. Social Indicators Research, 110, 613-635. DOI: $10.1007 / \mathrm{s} 11205-011-9948-9$.

PELLEGRINI, G., TERRIBILE, F., TAROLA, O., MUCCIGROSSO, T., BUSILLO, F. (2013). Measuring the effects of European regional policy on economic growth: A re- 
gression discontinuity approach. Papers in Regional Science, 92, 217-233. DOI: 10.1111/j.1435-5957.2012.00459.x.

PERCOCO, M. (2013). Strategies of regional development in European regions: Are they efficient? Cambridge Journal of Regions, Economy and Society, 6, 303-318. DOI: $10.1093 /$ cjres/rst011.

PETMESIDOU, M. (2017). Can the European Union 2020 strategy deliver on social inclusion? Global challenges. In Working Paper Series, No. 3. Bergen (University of Bergen), p. 24.

RAPPAI, G. (2016). Europe en route to 2020: A new way of evaluating the overall fulfillment of the Europe 2020 strategic goals. Social Indicators Research, 129, 77-93. DOI: 10.1007/s11205-015-1092-5.

RODRIGUEZ-POSE, A., FRATESI, U. (2004). Between development and social policies: The impact of European structural funds in objective 1 regions. Regional Studies, 38, 97-113. DOI: 10.1080/00343400310001632226.

SHIH, H. S., SHYURB, H. J., LEE, E. S. (2007). An extension of TOPSIS for group decision making. Mathematical and Computer Modelling, 45, 801-813. DOI: 10.1016/ j.mcm.2006.03.023.

SMITH, A., TIMÁR, J. (2010). Uneven transformations: Space, economy and society 20 years after the collapse of state socialism. European Urban and Regional Studies, 17, 115-125. DOI: $10.1177 / 0969776409358245$.

SOUKIAZIS, E., ANTUNES, M. (2006). Two speed regional convergence in Portugal and the importance of structural funds on growth. Ekonomia, 9, 222-241.

TILFOR, S., WHYTE, P. (2010). The Lisbon scorecard X. The road to 2020. London (Centre for European Reform).

VARRÓ, K., FARAGÓ, L. (2015). The politics of spatial policy and governance in post1990 Hungary: The interplay between European and national discourses of space. European Planning Studies, 24, 39-60. DOI: 10.1080/09654313.2015.1066760.

WALBURN, D. (2010). Europe 2020. Local Economy, 25, 699-702. DOI: $10.1080 / 02690942.2010 .533420$.

\section{Martin Plešivčák}

\section{AKO SÚ ÚSPEŠNÉ ČLENSKÉ ŠTÁTY PRI PLNENÍ PRIORÍT POLITIKY SÚDRŽNOSTI EÚ?}

Predložená štúdia sa zamerala na zhodnotenie úspešnoști členských krajín pri dosahovaní progresu v hlavných indikátoroch kohéznej politiky EÚ, so špeciálnou pozornost’ou venovanou krajinám Vyšehradskej štvorky. Slovensko, Česko, Pol'sko a Mad'arsko boli pri dosahovaní ciel'a inteligentného rastu vysoko nadpriemerné, pričom ciele udržatel'ného a inkluzívneho rastu sú $\mathrm{v}$ ich prípade na úrovni priemeru EÚ. V celkovom hodnotení (pre všetky tri priority) však patria medzi európsky nadpriemer.

Pri posudzovaní krajín však existujú určité obmedzenia pri zisteniach a ich výpovednej hodnote. Uskutočnilo sa porovnanie týkajúce sa vývoja hodnôt, nie ich súčasnej úrovne. Hodnotenie výsledkov politiky súdržnosti by však malo byt' v kontexte regionálnej politiky EÚ spojené najmä s ciel’om konvergencie. Prezentovaná analýza nereflektuje, ako sú dostupné hodnoty vzdialené od ciel'ových hodnôt. Nebolo to možné vyhodnotit' z viacerých dôvodov, napr. z dôvodu nekonzistentnosti údajov, faktu, že ciel'ové hodnoty sú stanovované samotnými krajinami atd'. Preto si skúmaná problematika vyžaduje d’alší výskum, ktorý je prioritne závislý od komplexnejšej databázy na úrovniach NUTS2, resp. NUTS3 (absencia konzistentných údajov). Hodnotenie bolo do istej miery s vysokou pravdepodobnost'ou ovplyvnené aj populačnou vel'kost'ou a ekonomickou rozvinutost'ou jednotlivých krajín, ked’že populačne dve najmenšie krajiny EÚ, Malta a Luxembursko, obsadili v rámci rebríčka hraničné pozície. Pri malých a menej rozvinutých krajinách jeden väčší projekt, 
resp. súbor projektov (opatrení) i v jednej konkrétnej oblasti, môže spôsobit' pomerne vel'ký posun krajiny ako celku vpred za relatívne krátke obdobie. Pri Luxembursku (a d'alších krajinách s vyspelou ekonomikou a vysokou životnou úrovňou) je zasa potrebné uvažovat' aj nad možným stavom saturácie (sú "príliš rozvinuté", čo limituje priestor na ich dynamickejší posun vpred). Další problém hodnotenia spočíva v diskusii o tom, či sledovaný progres nemôže byt' sčasti spôsobený opatreniami národnej politiky, a nie európskej. Vynára sa tu rovnako potreba sledovania vnútrnoštátnych či vnútrospoločenských rozdielov, ked’že pozitívne čísla za krajinu ako celok ešte nemusia nevyhnutne znamenat', že sa stav spoločnosti zlepšuje $\mathrm{v}$ prospech väčšiny obyvatel’ov daných krajín, žijúcich v ekonomicky, environmentálne a sociálne rôzne vyspelých regiónoch EÚ i samotných členských krajinách. Nevyhnutnou podmienkou sledovania týchto vnútroštátnych trendov je však existencia komplexnej databázy indikátorov kohéznej politiky na úrovni NUTS2 a nižšej, ktorá, žial', zatial' nie je realitou. 
